\title{
A RHETORICAL ANALYSIS OF PHILIPPIANS 1:12-26
}

\author{
A.H. Snyman ${ }^{1}$
}

\begin{abstract}
In this article Philippians 1:12-26 is analysed from a rhetorical perspective that differs from the typical approach of researchers, who tend to force ancient rhetorical categories on a letter. The analysis is done in terms of what is called a "grounded theoretical approach". This approach is briefly summarised, followed by a systematic analysis of Paul's basic rhetorical strategy, as well as all the supportive rhetorical techniques in these fifteen verses. It will be argued that these verses are an integral part of Paul's rhetorical strategy, constructed from the text itself and aimed at reassuring the Philippians that his adversities are for the advancement of the gospel. The conclusion is that a text-centred approach with its focus on the functional aspects of the text, provides a better understanding of Paul's rhetorical strategy than a typical rhetorical analysis, with its focus on the formal aspects of the text.
\end{abstract}

\section{INTRODUCTION}

Rhetorical analyses over the past two decades have been dominated by the pioneering work of H.D. Betz, Galatians. A commentary on Paul's Letter to the churches in Galatia (1979). Although the initial reaction to the commentary was, on the whole, favourable, scholars like the German classicist Joachim Classen (1993) started questioning Betz's use of the two disciplines of epistolography and rhetoric, and especially the aim of applying ancient rhetorical categories to Paul's letters. Is the aim to demonstrate to what extent Paul was familiar with these categories, or to arrive at a better understanding of a particular letter? If the aim is a more adequate appreciation of Paul himself, where, when and how did he become familiar with ancient rhetoric and epistolography, and did he draw on such knowledge deliberately or not? If the aim is a more thorough understanding of a letter, should one restrict oneself to the categories of ancient rhetoric, or should one also employ new aspects that have been added since antiquity? (Classen 1993:267-268).

1 Prof. A.H. Snyman, Research Fellow, Department of New Testament, University of the Free State, Bloemfontein 9300. 
As a result of these and other legitimate questions, New Testament scholars started analysing Paul's letters without using ancient rhetorical categories. Instead of forcing these categories on a letter, they began to apply modern rhetorical theories, or they analysed the arguments in a letter in terms of a text-centred approach (that is, the letter itself serves as the starting-point for the analysis). Examples are the analyses of Anderson (1999) on Galatians 1-5:12, Romans 1-11 and 1 Corinthians, the work of Kern (1998) on Galatians and Tolmie's analysis of the same letter (2004).

The purpose of this article is to analyse Philippians 1:12-26 in terms of Tolmie's proposal for rhetorical analysis. The main trends of his proposal will be summarised, followed by an analysis of Philippians1:12-26. I hope to prove that a text-centred approach aimed at reconstructing Paul's rhetorical strategy from the text itself, provides a better understanding of his rhetoric than an approach where external rhetorical categories are forced upon the text.

\section{TOLMIE'S PROPOSAL FOR A TEXT-CENTRED APPROACH TO RHETORICAL ANALYSIS}

Since it is impossible to read or analyse a text in a totally objective way, Tolmie (2000:122-123 and 2004:36-39) gives an explanation of the approach that he used in analysing the letter to the Galatians. His purpose is not to prescribe a fixed methodology, but to construct Paul's rhetorical strategy from the text itself. This can only be done once the situation that called forth the letter has been constructed. Thus the starting-point of any analysis is a construction of the rhetorical situation, that is, the broad outline of what Paul wants to achieve in the letter as a whole.

The rhetorical situation is then followed by a text-centred descriptive analysis of how Paul attempts to persuade his audience. As a general guideline Tolmie (2004:37) formulated what he called "a minimal theoretical framework", consisting of the following aspects:

- The identification of the dominant rhetorical strategy in a particular section by answering two questions: How can one describe 
Paul's primary rhetorical objective in the section, and: How does he attempt to achieve this objective? The principle used to demarcate a section is a change in Paul's rhetorical strategy.

- The analysis itself is done in various ways, without following a fixed methodology. It could be done by focusing on the type of arguments Paul uses and why they are effective. In other sections it is better to describe the way in which he argues instead of focusing on the type of arguments used. One should also distinguish between the dominant rhetorical strategy and supportive rhetorical strategies, that is, strategies that cannot be related directly to the dominant strategy, but are important in terms of the overall argument of the letter.

- The various ways in which Paul enhances the impact of his communication should also be identified. These so-called "rhetorical techniques" are well-known and include the use of rhetorical questions, metaphors, chiasms, the way sentences are structured, etc. The functions of the techniques are important and should also be described.

- The organisation of the argument in the letter as a whole needs to be addressed once the analysis of the letter has been completed.

In order to understand Paul's rhetorical strategy in each section, one must understand what he is saying to his audience. Thus, exegetical issues should be addressed, especially when there is not agreement on the meaning of a specific phrase or expression. The principle is, once again, the rhetorical impact of the exegetical issue, and not the issue as such.

\section{PHILIPPIANS 1:12-26}

\subsection{Introduction}

According to many commentators the situation that called forth the letter was the monetary gift that Paul had received from the Philippians through their emissary Epaphroditus (Müller 1976:13-14; Matter 1965:11; Hendriksen 1971:9-20, etc.). The gift was a clear sign of the deep personal relationship between Paul and the church in Philippi. This relationship existed from the founding of the church 
up to the present, and commentators like Marshall (1987:35-69) and Brown (1997:486) regard the maintenance of this friendship as the main motivation for the letter.

That the letter has undertones of friendship cannot be denied. It is replete with language and concerns of friendship, as is clear from its very beginning $(1: 3-4,7,8)$. In his construction of the situation in Philippi, however, Silva (1988:21) comes to a different conclusion. He argues

that the Philippians were facing great adversity, had lost their sense of Christian joy and were tempted to abandon their struggle.

The believers in Philippi were experiencing a lack of unity and many of them had lost their confidence in maintaining their Christian confession. Consequently, Paul responded by persuading them to stand fast and to persevere. ${ }^{2}$

I find Silva's construction of the situation convincing, since it covers various aspects of the church life in Philippi. The letter must be seen as a response to the problems in Philippi - that Macedonian city to which Paul refers as constituting "the beginning of the gospel" (4:15). Therefore he wrote the letter to persuade his fellow-Christians, with whom he had a deep personal relationship, to persevere in proclaiming and living the gospel that they received at the founding of the church in Philippi.

In 1:1-11 the focus was on the Philippians' continued co-operation in proclaiming the gospel (1:3-8), as well as on their perseverance in living the gospel (1:9-11). Here in 1:12-26 the focus shifts to the perseverance of Paul and the brothers in Rome as he tries to reassure the Philippians of the progress of the gospel as a result of his own adversities. He attempts to assure them that, whatever they may have heard or whatever his circumstances may be, nothing has suppressed or will suppress the proclamation and progress of the gospel. Paul's overall rhetorical strategy in 1:12-26 could thus be described as reassuring the Philippians by informing them that his imprisonment and possible execution are for the advancement of the gospel.

2 For a detailed description of the context of the letter, see Silva (1988:1-10). O'Brien (1991:36-38) and Fee (1995:32) are also in agreement with this focus on the situation in Philippi. 
Philippians 1:12-26 is demarcated by rhetorical considerations. The section is separated from 1:3-11 by the disclosure formula $\gamma(\nu \omega \sigma \sigma \kappa \in \omega \nu$ $\delta$ $\delta \dot{~ u \mu a ̂ s ~ \beta o u ́ \lambda o \mu a l, ~ a ̉ \delta \in \lambda \phi o i ́ ~(" I ~ w a n t ~ y o u ~ t o ~ k n o w, ~ b r o t h e r s ") ~ i n ~ 1: 12 . ~}$ In what follows, Paul is informing his audience about the progress of the gospel as a result of - and not despite - his imprisonment (1: 12-17) and his possible execution (1:18-26). A new section begins with $1: 27$, where Paul's rhetorical strategy shifts from the sharing of information to various exhortations. The first person singular, which characterises 1:12-26, also distinguishes this section from the preceding (1:3-11) and following (1:27-30) ones.

The two phases in 1:12-26 are 1:12-17 and 1:18-26. The main reason for this division is the rhetorical question in $1: 18$. It serves to summarise the preceding phase $(1: 12-17)$ and to introduce a new one (1:18-26). The repetition of the verb xaípw ("rejoice") links the two parts of verse 18, while the ráp at the beginning of $1: 19$ explains what is said in 1:18. Linguistically, the future tenses in 1:18b-26 distinguish it from the preceding 1:12-17, while the "noetische Verben"

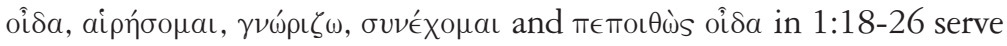
the same purpose (Schenk 1984:144).

Before commencing with a detailed analysis of the two phases, it is necessary to make two further remarks on the section as a whole:

First, Watson (1988:58-60), who follows Betz in his approach to rhetorical analysis, defines 1:12-26 as part of the exordium of the letter. He identifies three main functions of an exordium: "to obtain audience attention, receptivity and goodwill" (Watson 1988:62). Goodwill is also obtained

by concentrating upon the facts of the case and the persons involved, including the rhetor, the audience and the opposition.

However, the main problem with describing 1:12-26 as part of the exordium and limiting its function to obtaining goodwill, is that it leads to a degradation of the argumentative value of this part of the letter. As Tolmie (2004:53) points out in his analysis of Galatians, the exordium and narratio cannot merely be regarded as "preparatory" for the "real" arguments in the probatio. On the contrary: it may be that Paul prefers to use his best arguments first. 
Secondly, Philippians 1:12-26 is a detailed account of the apostle's current circumstances. Paul usually covers this topic toward the end of his letters, in connection with the so-called travelogue (Rom. 15:2233; 1 Cor. 16:5-12; 2 Tim. 4:9-14). The fact that he discusses it in the very first chapter of this letter, is a distinctive and rhetorical significant feature of Philippians. As a crucial issue for him and his audience he inserts it here at the beginning of the letter. This fact is important for modern readers, but the Philippians would not have realised this. However, the "ironic turn of events" (Silva 1988:68) in 1:12 could not have gone unnoticed. The church at Philippi was concerned about Paul's imprisonment and its implications. Logically his imprisonment could only repress their interest in the gospel and add to their distress. By way of an ironic turn of events, however, Paul informs them that his ministry was not curtailed by his imprisonment, but that the imprisonment actually turned out for the advancement of the gospel. This ironic turn of events serves to capture the attention of the audience and to stress the pre-eminence of the gospel.

\subsection{Philippians 1:12-17. Informing the Philippians that his imprisonment was for the advancement of the gospel}

Paul begins this phase in his argument by using a well-known disclosure

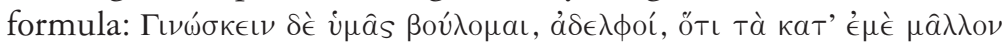

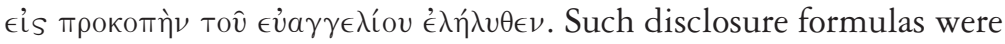
used in many papyri letters and consists of four elements:

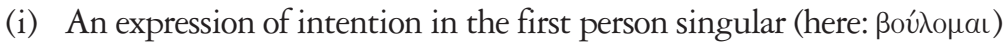

(ii) A verb of knowing in the infinitive ( $\gamma \iota \nu$ ó $\kappa \kappa \in \iota \nu)$

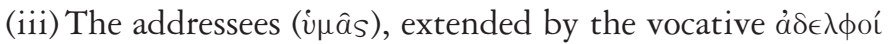

(iv) Information (introduced by öTı). (Schenk 1984:132, with reference to the article of Mullins in Novum Testamentum 1964.)

Paul normally uses a disclosure formula to introduce formal assertions (see 1 Cor. 12:3; 15:1; Gal. 1:11 and 2 Cor. 8:1). In 1:12 it serves as a marker drawing the attention of the audience to what follows. The direct address $a \dot{\delta} \in \lambda \phi o$ has a similar function in that it serves as an indication to the audience that something new is to be introduced, something really important (Schenk 1984:133). The important 
issue introduced here is that the things that have happened to him, namely his imprisonment, in reality turned out for the advancement of the gospel. (For the irony inherent to this statement, see 3.1 above.)

The way in which this progress has been achieved is described in 1:13-14. First, his imprisonment has affected the praetorian guard

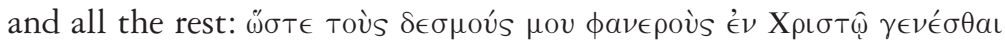

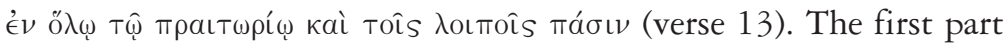

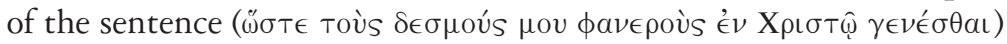
may be rendered "so that my imprisonment in the cause of Christ has become well-known”. The use of '́ $\nu$ X way Paul's solidarity with Christ: he was in prison not for any crime he has committed, but only for his connection with the Christ whom he proclaims. And this message spread from guard to guard and eventually to "all the rest", that is, to all who were associated with the praetorian guard and knew about his circumstances. Paul's case, or rather Christ's cause, became "the talk of the town". This means progress for the gospel as the real issue at stake (Hendriksen 1962:69).

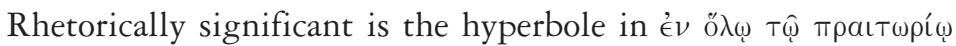

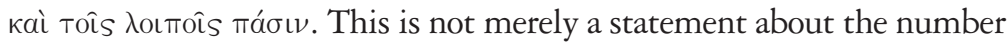
of people that got interested in the gospel; it is an indication of its broad impact on the people of Rome.

The second evidence of Paul's claim that his imprisonment has turned out for the advancement of the gospel, is the fact that the majority of the brothers, having gained confidence in the Lord ('́ $\nu$ кupí $\omega$ $\pi \in \pi$ olÓ́tas) as a result of his imprisonment, are becoming exceedingly bold to speak the word of God without fear. Instead of being intimidated by his imprisonment, the brothers were actually encouraged to become bolder witnesses. This is inside evidence for the ironic turn of events referred to in 1:12: not only the praetorian guard and all the others out there, but the majority of Paul's own brothers, became bolder witnesses for the advancement of the gospel.

Important for the argument here is that the real cause of their courage was not Paul himself or his imprisonment, but their confidence

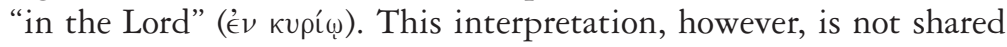
by all commentators and translators. The problem is that év кupí placed between "the brothers" ( $\tau \hat{\omega} \nu \alpha \dot{\alpha} \delta \in \lambda \phi \hat{\omega} \nu)$ and "having confidence" 
( $\pi \epsilon \pi$ oเӨótas) in the Greek text, making it possible to connect it with either one of the two. Osburn (1971:28), Bruce (1983:18) and Fee (1995:109-110) connect it with "the brothers" and interpret it as "the brothers in the Lord" (So also the KJV, $A S V$ and $N A B$ ). Other commentators (Hendriksen 1962:70; Müller 1976:50; Gnilka 1976:54; Loh and Nida 1977:21; Silva 1988:68 and O’Brien 1991:94-95) regard this connection as redundant and prefer to connect év кupí with "having confidence". Reasons for their preference are that the construction is used later on in the epistle (2:24), as well as elsewhere in Paul's letters (Rom. 14:14; Gal. 5:10). If this is correct, év кupí $\pi \in \pi$ otӨótas is rhetorically significant. It is an argument based on divine involvement. God is involved by giving them the confidence to proclaim the gospel without fear. The fact that he is involved assures a bold proclamation — and thus the progress — of the gospel. ' $\epsilon$ кupí $\omega$ could also serve as a subtle reminder that the gospel that is proclaimed is of divine origin.

In 1:15-17 Paul expands in chiastic fashion on the toùs $\pi \lambda \in$ íovas T⿳ิे

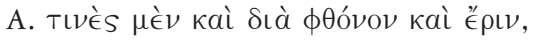

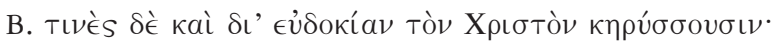

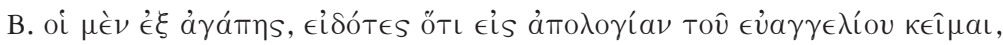

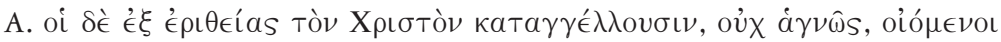

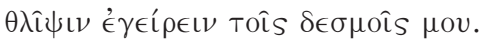

Paul refers to two classes of preachers with different motives. He begins with those who are uppermost in his mind; the brothers who proclaim the gospel with impure motives (oux à $\gamma \nu \hat{\omega} s$ ). According to Schenk (1984:138), Silva (1988:72) and Fee (1995:19), these people are foregrounded by the chiasm. None of them, however, is a preacher of false doctrine. None is preaching "a different gospel”, like Paul's opponents in Galatia (Gal. 1:6). But while they are proclaiming the true

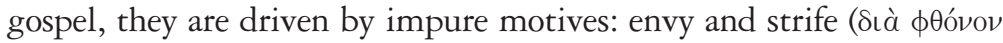
кai ё $p \iota \nu, 1: 15)$. In 1:17 Paul uses a different preposition and noun to describe their attitude: out of strife ( $\left.{ }^{\prime} \xi \xi \dot{\epsilon} p t \theta \epsilon i a s\right)$. While the preposition É K more clearly than sía refers to attitudes as sources of behaviour, Silva (1988:73) is of the opinion that a semantic distinction between the two is neutralised in this context. The variation is purely stylistic. 
The same applies to the difference between épıs in 1:15 and épıt $\theta$ eía in 1:17. Silva's interpretation is supported by the chiasm in 1:15-17.

The second group consisted of those preachers who were motiva-

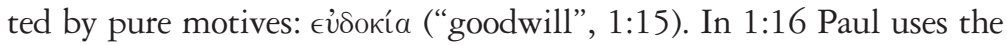

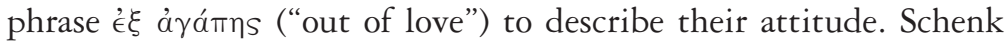
(1984:140) is of the opinion that the words are contextual synonyms, used for stylistic variation. His interpretation is also supported by the chiasm.

Rhetorically significant is the phrase "knowing that I am appointed for

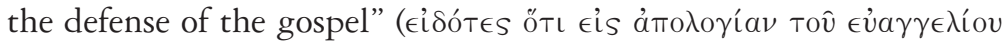

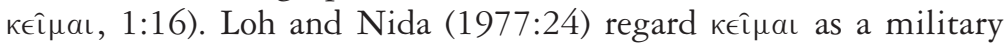
term that describes a soldier posted as a sentinel. Here it is used figuratively with the meaning of "to be appointed" or "to be chosen", as in Luke 2:34. The appointment comes from God, and thus they translate: "God has given me the work of defending the gospel" (1977:22). ${ }^{3}$

The type of argument used here is another example of an argument based on divine involvement. Since God has called him to defend the gospel, those preachers who were motivated by goodwill and love had been emboldened to proclaim the gospel without fear. They do so out of love for the man, whom they knew had been appointed by God for the defence of the gospel.

Now that Paul's rhetorical strategy in 1:12-17 has been outlined, it is necessary to draw attention to the rhetorical techniques used here.

- The word прокоти́, used in 1:12 (and again in 1:25), is a military metaphor describing a scout who removes obstacles before an advancing army (Loh and Nida 1977:20). This word signifies the advancement of the gospel in a very graphic way.

- Implicit in 1:12 is the recognition that God is at work in the affairs of men. The recognition is veiled by the impersonal é $\lambda \hat{\eta} \lambda u \theta \in v$ ("come about") and refers to God as the real actor in the ironic turn of events described in this verse (Silva 1988:71-22). If correct, it is also an argument based on divine involvement.

3 So also Bruce (1983:20); Gnilka (1987:62); O’Brien (1991:100); Fee (1995:120) and Müller (1993:53). 
- O'Brien (1991:97-98) draws attention to the "well-rounded and carefully constructed piece of writing" in 1:15-17, in which antithetic parallelisms occur in 1:15 and 1:16-17; and the already mentioned chiasm in 1:15-17.

Antithetic parallelisms:
i) Tเvès $\mu$ èv kaì $\delta \iota^{\prime}$
TLvès $\delta$ Kè kaì $\delta \iota^{\prime}$
ii) oi $\mu \grave{\epsilon} \nu \grave{\epsilon} \xi$
oi $\delta \grave{\epsilon} \dot{\epsilon} \xi$

And the chiasm:

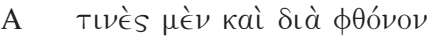

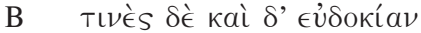

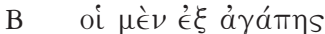

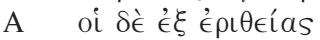

Why would Paul do this? Tolmie (2004:141) is probably correct when he says that such structures should not merely be seen as forms of embellishment. Ideas expressed in such a neat way also focus the attention of the audience on the content of what is said. Here it serves to focus attention on the two types of preachers distinguished by Paul.

To summarise: Paul's rhetorical strategy in 1:12-17 can be described as "informing the Philippians that his imprisonment was for the advancement of the gospel". He introduces his argument by using a well-known disclosure formula (1:12), thereby drawing attention to what follows. The direct address $\dot{a} \delta \in \lambda \phi o$ has the same function: it is an indication that something new is to be introduced. The ironic turn of events in 1:12 serves to capture the attention of his audience and to stress the pre-eminence of the gospel: his imprisonment has in reality turned out for the advancement of the gospel.

In 1:13-14 Paul describes the way in which this progress has been achieved. First, his imprisonment has affected the praetorian guard

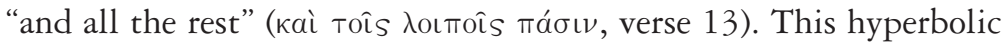
statement is used to indicate the broad impact of the gospel. Secondly, "the majority of the brothers" gained confidence "in the Lord" ('̇ $v$ кupí $\omega$ ) to speak the word of God without fear. év кupí $\omega$ points to divine involvement as the real cause of their boldness in proclaiming the gospel. It could also serve as a subtle reminder that the gospel is of divine origin. 
In 1:15-17 Paul expands in chiastic fashion on "the majority of the brothers" (verse 14) by distinguishing between those who preach the gospel with impure motives, and those motivated by goodwill and love. The chiasm in 1:15-17 has two functions:

- It highlights the first category who proclaim the gospel with impure motives, as over and against those who proclaim it out of goodwill and love. Both categories, however, proclaim the true gospel.

- It supports the view that the prepositions and nouns used in 1:15 and $1: 17$ on the one hand, and $1: 15 \mathrm{~b}$ and $1: 16$ on the other, are not semantic distinctions, but used for stylistic variation.

In 1:16 there is another example of an argument based on divine involvement. God has given Paul the work of defending the gospel. Those who proclaimed the gospel with pure motives did so out of love for the man whom they knew God had appointed.

Three rhetorical techniques have been identified in 1:12-17. The first is the military metaphor прокопи (1:12), which signifies the advancement of the gospel in a graphic way. The second is the impersonal

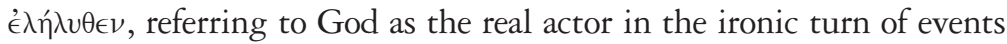
in $1: 12$. And finally, the antithetic parallelism in $1: 15$ and 1:16-17, as well as the chiasm in 1:15-17, all focus the attention on the content of what is said. Here it serves to focus attention on the two types of preachers that Paul distinguishes.

\subsection{Philippians 1:18-26. Informing the Philippians that his adver-}

sities will result in his salvation and the progress of the gospel

Philippians 1:18 has a bridging function. On the one hand it summarises the preceding argument that, as a result of his imprisonment, the gospel has been proclaimed - be it by preachers with pure or impure motives. This is Paul's first assurance. The second one, also introduced by a verb of knowing (oi $\delta a, 1: 19$ ) is that his adversities will result in his salvation. The two statements are connected by the verb

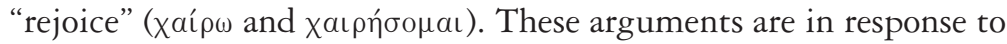
a situation where believers "were facing great adversity, had lost their sense of Christian joy, and were tempted to abandon their struggle" (Silva 1988:21). 
Paul introduces this phase of his argument by using a rhetorical

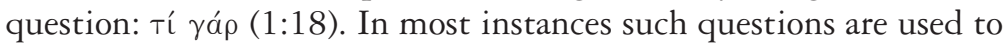
convey a particular notion forcefully (Tolmie 2004:143). Here it is used to convey his joy concerning the progress of the gospel and his own salvation. The repetition of xaí $\rho \omega$ conveys the statement in 1:18 with more emotional effect.

In 1:19-26 Paul explains his assurance that his adversities will result in his salvation ( $\sigma \omega \tau \eta \rho i \alpha)$ and the progress of the gospel. From an exegetical point of view the meaning of the term $\sigma \omega t \eta p i ́ a$ is debated. There are three viewpoints. The first, preferred by Loh and Nida (1977: 29), is to interpret it as Paul's release from prison due to the prospect of seeing his friends again $(1: 25-26)$. The second is to interpret it in a broad sense, in that it includes Paul's ultimate salvation and his release from prison (Osburn 1971:33 and Fee 1995:132). And thirdly, Gnilka (1976:66), Silva (1988:76-78) and O'Brien (1991:109-110) opt for a soteriological interpretation for, amongst others, the following reasons:

- the recognition that Paul is here alluding to Job 13:13-18 in the LXX which deals with Job's eternal destiny, his standing before God;

- the pathos in Paul's comment in 1:20: "in accordance with my eager

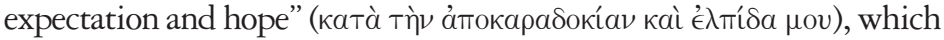
cannot be minimised by a mere reference to physical freedom,

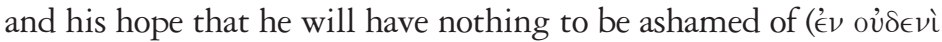
ai $\sigma \chi v \nu \theta \eta \dot{\sigma o} \sigma a \mathrm{l})$, but that Christ will be glorified ( $\mu \in \gamma a \lambda \nu \nu \theta \dot{\eta} \sigma \in T a \mathrm{l})$ in his body. In Romans 5:5 the compound кataloxívoua is also used in the context of Christian faith and perseverance, turning attention to matters of eternal import.

It is difficult to make a decision. In my opinion, the context here

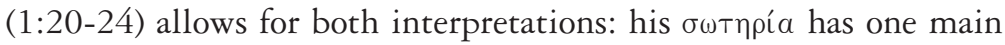
purpose and that is to magnify Christ - be it in this life or hereafter. The primary reference in 1:19 is to Paul's faith and perseverance, as Silva (1988:78) correctly points out. This remark is supported by 2 Timothy 4:18, where similar terms are used: "The Lord will rescue

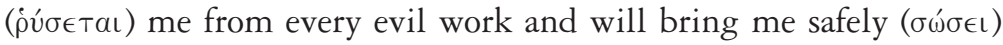
to his heavenly kingdom". Put differently in terms of perseverance: 
"I have kept the faith" (2 Tim. 4:7). The reference to perseverance is important in the light of the rhetorical situation of the letter.

As reasons for his deliverance Paul mentions two factors: the prayers

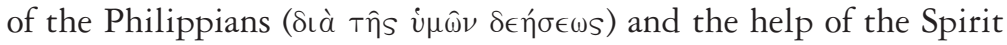

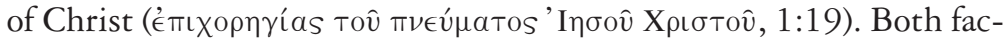
tors are rhetorically significant. The first is that his perseverance will be the result of the prayers of his fellow-believers, their supplication. In 1:4 Paul makes supplication for the Philippians; here (in 1:19) they are doing the same for him. This indicates that the fellowship, the close relationship between them, is operating (Hendriksen 1962:74).

The second reason is hotly debated by exegetes and translators: ( $\delta$ เ $)$ )

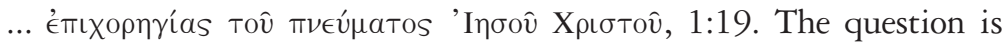
whether this construction should be interpreted as an objective or a subjective genitive. If objective, the Spirit is that which is given ("the Spirit of Jesus Christ is given me for support," NEB). Silva (1988: $79)$ is in support of this reading when he translates: "through Jesus Christ's provision of his Spirit". So also Fee (1995:133), who prefers an objective genitive because the noun does not mean "help," but "supply". "Supply" requires an object and here the object is the Spirit.

The other possibility, preferred by Collange (1979:60), O'Brien (1991:111-112) and Müller (1993:57) is to regard it as a subjective genitive, in which case "the Spirit of Jesus Christ "would be the giver: "the help which the Spirit of Jesus Christ gives" (TEV). In my opinion this interpretation is to be preferred for two reasons:

- It suits the context better (see the active role of God in 1:12, 1:14 and 1:16), and

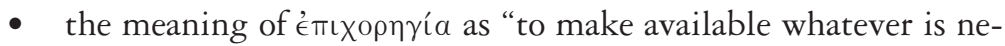
cessary, to help or supply the needs of someone - to provide for, to support, to supply the needs of, provision, support" (Louw and Nida 1988:461-462). They translate 1:19 as: "what the Spirit of Jesus Christ will provide for......”.

If correct, it is another example of an argument based on divine involvement. The help, which the Spirit of Christ provides, will ensure Paul's deliverance; the Spirit will enable him to persevere till that joyful event. 
Thus Paul's deliverance will be the result of two factors: the one human, the other divine. It recalls 1:6-7, where Paul is assured that the co-operation of the Philippians will continue till the very end, because God is involved and their lives had provided evidence of their co-operation and perseverance.

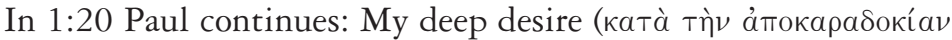

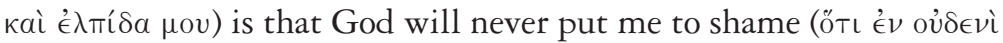
ai $\sigma \times v \nu \theta \eta \dot{\sigma o \mu a l), ~ b u t ~ t h a t ~ a t ~ a l l ~ t i m e s, ~ b u t ~ e s p e c i a l l y ~ n o w, ~ I ~ s h a l l ~ b e ~}$ full of courage, so that with my whole being I shall bring honour to Christ, whether I live or die.

The rendering "God will never put me to shame" differs from the majority of English and Afrikaans translations (RSV, TEV, CEV, 1983 Afrikaans translation, Die Boodskap, etc.). The main question is whether the verb aioxvivoral is to be regarded as medium or passive voice. If as a medium, it could be translated: "be ashamed"; the passive could be rendered "be put to shame" (Arndt and Gingrich 1957:25).

Which one is to be preferred? In an article on translation issues in the letter to the Philippians, Tolmie (2000:221-222) argues that the context here probably points to the translation "that God will not disgrace/disappoint me". Two factors support his choice:

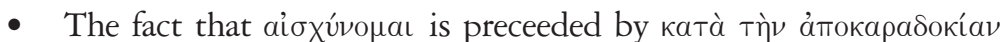

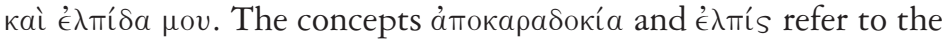
expectation that God will do something in future, as is clear from

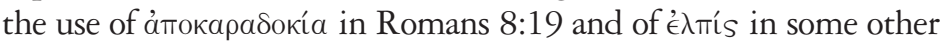
New Testament contexts, where the future expectations of believers

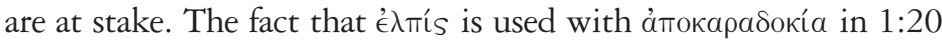
makes it quite certain that it refers to what God is about to do in future.

- The use of aioxúvouar with $\mu \epsilon \gamma a \lambda$ v́oua in 1:20. Tolmie refers to Gnilka (1976:67-68), who calls attention to the fact that these two terms are used in the LXX and the Qumran Hodayot to express the antithesis between the enemies of God, whom he puts to shame, and the righteous who magnifies God. The reference to Job 13:16 in the previous verse (1:19) supports the view that Paul is using "Old Testament language" here, and that aioxúvoua should not be rendered: "I shall never be put to shame," but rather: "God will not 
put me to shame". Tolmie proposes the translation: "dat God my nie sal teleurstel nie" (2000:222; see also the translation of Schenk, 1984:164: "Gott wird mich in keiner Lage preisgeben").

If correct, it is yet another example of an argument based on divine involvement. It is the apostle's sincere expectation and hope that God will not disappoint him in his endeavours to magnify Christ. On the contrary, God will equip him with all boldness to magnify his Lord, to proclaim the gospel with unfailing courage. He will persevere and succeed, because God will enable him to do so - whether he is alive

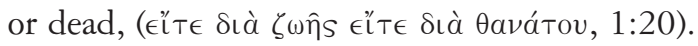

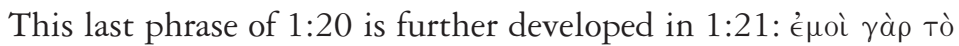
$\zeta \hat{\eta} v$ X and to die [is] gain”). The Greek quotations from 1:20 and 1:21 are structured in parallel and introduce a series of brief sentences, stretching

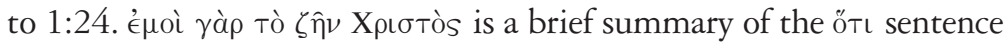
in 1:19 and 1:20, as well as an explanation of $\zeta \omega \eta$ in 1:20. It poses no problems. But how can his death be considered advantageous ("gain")? Loh and Nida (1977:32) suggest two possibilities: First, since his life finds its meaning in Christ, it stands to reason that his death (which means being with Christ, 1:23) is an advantage. Secondly, his death will be advantageous because his martyrdom would lead to the progress of the gospel. This is probably what képঠos here in this context communicates. If correct, it recalls the irony of 1:21: The apostle's adversity results in the advancement of the gospel.

Philippians 1:22 confronts us with a difficult syntactical problem. In Greek it has three clauses:

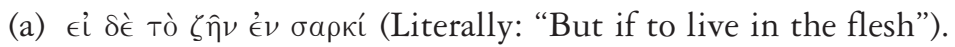

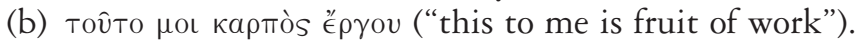

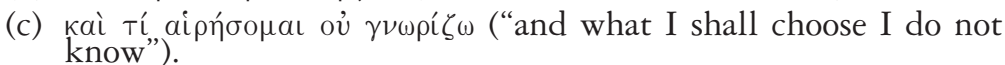

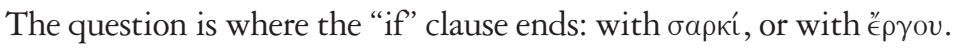
The NIV takes (a) as the protasis, (b) as the apodosis and (c) as a separate sentence: "If I am to go on living in the body, this will mean fruitful labour for me. Yet, what shall I choose? I do not know". So also Gnilka (1976:69), O'Brien (1991:124-126) and Fee (1995:139, 143-144). Silva (1988:80) on the other hand, takes (a) and (b) as the 
protasis, and (c) as the apodosis: "If, nevertheless, living in the flesh means fruitful labour, then I cannot decide what to do". So also Collange (1979:33) and Schenk (1984:158). The majority of translations prefer the first option and regard (a) as the protasis, (b) as the apodosis and (c) as a separate sentence (REB, RSV, Groot Niews Bijbel, 1983 Afrikaans translation, etc.).

Which interpretation is to be preferred? Silva (1988:81) is probably correct in pointing out that all possibilities yield basically the same meaning. What is important, however, is to

appreciate the nature of the ambiguities in this verse, because the style tells us something of exegetical value regarding the emotional context of Paul's words.

According to Silva, Paul is not making an objective, theological statement here, but he is laying bare his soul and admits that he has "embarrassing feelings"; he experiences a tension between personal

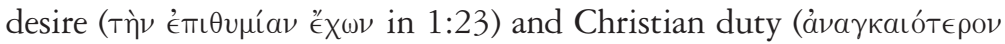
in 1:24). O'Brien (1991:124) also ascribes the grammar here to "a conflict of feeling in his mind." The verb ovvéxouaı (1:24) supports their interpretation. It is also used in Luke 12:50 and means: "to experience great psychological pressure and anxiety - to be distressed, to be troubled" (Louw and Nida 1988:315). Such "embarrassing feelings" could only be shared with true friends and are proof of the strong relationship between Paul and the Philippians.

In 1:23 and 24 Paul expresses his dilemma more clearly. On the one hand he has the desire to depart and be with Christ, for that is

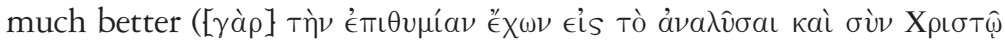

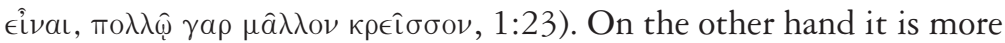

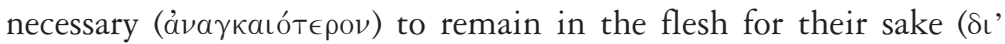

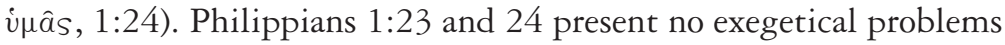
and spell out his options. The first one is much better, a far better

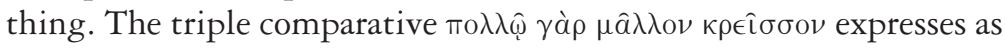
strong as possible the superior option of being with Christ, while

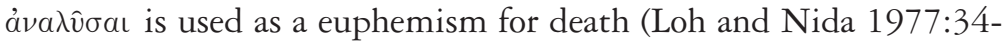

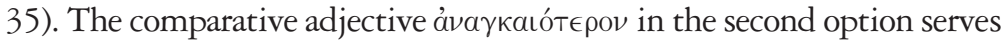
to reassure the Philippians of his duty towards them in an emphatic way: he is convinced that it is more necessary to stay alive $\delta \iota^{\prime}$ ' i $\mu$ âs ("for your sake, in order to help you") than to depart and be with Christ. 
The need of the church in Philippi weighs more than the personal desire of the apostle.

The following two issues are of rhetorical significance in 1:23 and 24. Firstly, the concise statements used to convey Paul's options to the Philippians. It begins at the end of 1:20 and continues up to 1:24. Such abbreviated expressions are generally used to enhance the forcefulness of statements (Tolmie 2004:76).

Secondly, 1:24 implies that the Philippians have definite spiritual needs and that by continuing his life on earth, Paul will be able to bestow further pastoral care upon them. The Philippians were confronted with real dangers (as is clear from 3:1-3, 3:19 and 4:2) and need the apostle's help (Hendriksen 1962:79). These needs prove that Silva's construction of the rhetorical situation is correct: the letter is a response to the problems experienced by the church in Philippi and not just a letter of friendship aimed at maintaining the relationship between Paul and his audience.

In 1:25-26 Paul reassures the Philippians by describing the purpose of his expected release and prolonged ministry as follows: Literally:

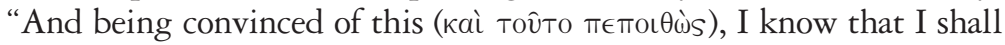

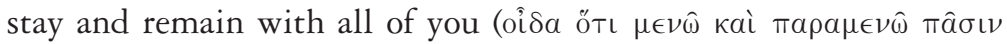

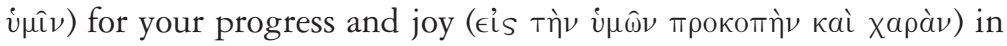

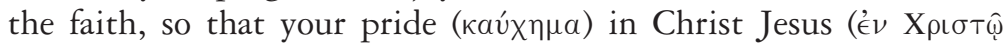

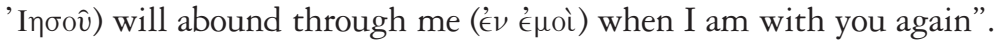

The purpose of his release is threefold: (a) their progress in the faith; (b) their joy in the faith, and (c) their exultation through his ministry among them. The only exegetical problem in these two verses is the question whether Christ Jesus or Paul is the object of "pride" in 1:26. In the above translation, Christ is the object (so also Loh and Nida 1977:36, the RSV and the 1983 Afrikaans Translation). The other pos-

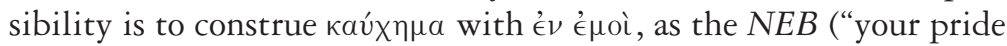
in me may be unbounded") and the TEV ("you will have even more reason to be proud of me ") have done. év X lated: "in your life in union with Christ Jesus", meaning that the Philippians' pride in him is developed in the sphere of Jesus Christ. ${ }^{4}$

4 So Osburn 1971:42. For a detailed discussion of the two possibilities, see Silva (1988:86) and Loh and Nida (1977:37). 
Schenk (1984:162) offers another solution. He argues convincingly

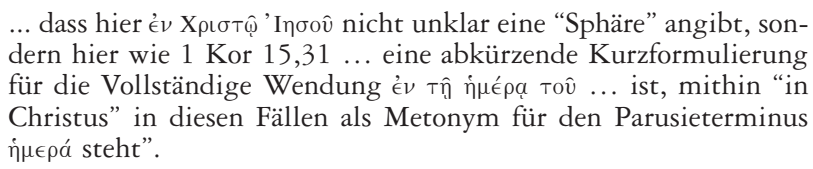

The interpretation is supported by the context. First, it recalls the

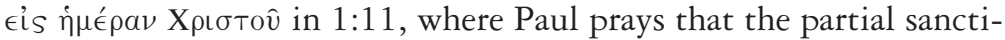
fication of the Philippians be brought to completion "at the day of

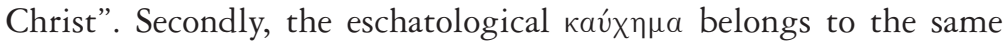

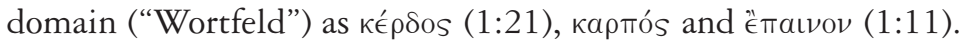

I find Schenk's proposal convincing because it seems to match the context best. At the same time it is not necessary to choose between

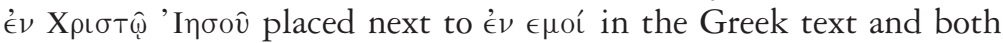

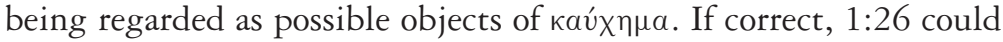
be translated: "So that, when I am with you again, your pride in me will abound on the day of Christ Jesus".

The rhetorical significance of this translation is that, although the Philippians were experiencing serious difficulties, the apostle's pre-

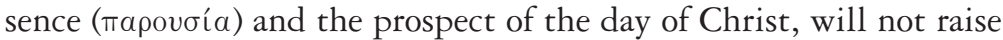
expectations of judgment (as in 2 Cor. 13:1-3, 10) but of joy. For believers, who are struggling with serious problems and had lost their sense of Christian joy, these prospects would have been most reassuring.

From a rhetorical perspective the following two constructions emphatically assures the Philippians that Paul will return and resume his duties among them:

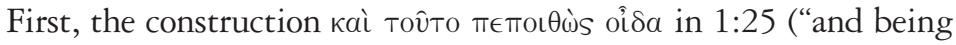
convinced of this, I know"). Tov̂To refers to the necessity that he stays on for the Philippians' sake. The verb oisa, in contrast to (for example) olópal in 1:17, stresses Paul's conviction in this regard (Silva 1988:

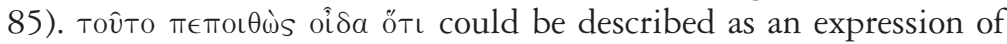
firm conviction, assuring the Philippians in an extremely powerful way of his choice to remain with them.

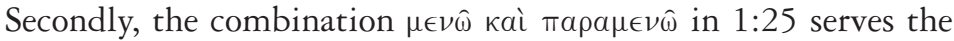
same purpose. Although commentators like Matter (1965:35), Osburn (1971:41) Müller (1976:56), Bruce (1983:31) and Fee (1995:152) 
tried to distinguish between the two words by adding a semantic component to $\pi \alpha \rho \alpha \mu \in \nu \hat{\omega}$, Silva (1988:85) regards the repetition as an example of stylistic reinforcement. The function of such reinforcement is to aid the communication process by emphasising his assurance that he will remain with them.

Other rhetorical techniques used to enhance the communication in 1:19-26 are the following:

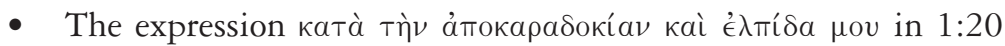
could be regarded as a hendiadys. This has led Silva (1988:75) to the translation "hopeful expectation." Schenk (1984:164) also translates: "Aufgrund meiner festgegründeten Hoffnung". The function of the hendiadys is to connect the two concepts ámокарабокі́a and 'ं $\lambda \pi i^{\prime} s$ as closely as possible, since they both refer to what God is about to do in future.

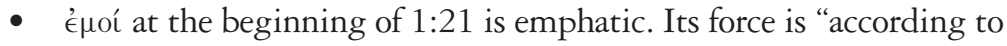
my own experience", in contrast to those who proclaim the gospel out of impure motives (1:15 and 1:17). "Paul, in contrast with them, is not self-centered, but Christ-centered" (Hendriksen 1962:76).

- Fee (1995:140-141) draws attention to the alliteration and assonance

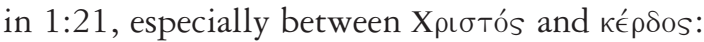

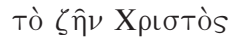

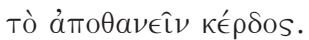

The effect of this assonance does not lie in form alone, "but in its singularly focused affirmation".

To summarise: Paul's rhetorical strategy in 1:18-26 can be described as "informing the Philippians that his adversities will result in his salvation and the progress of the gospel". He introduces his argument by using a rhetorical question in 1:18 that conveys his joy concerning the progress of the gospel and his own deliverance forcefully and with emotional effect. In 1:19 he mentions two reasons for his perseverance and eventual deliverance: the prayers of the Philippians (which proves that the close relationship between Paul and the Philippians is working) and the help that the Spirit of Jesus provides (an

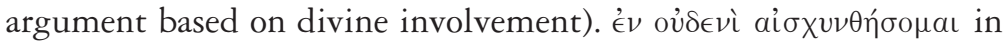
1:20 is also an argument based on divine involvement: God will not 
disappoint Paul in his endeavours to magnify his Lord and to proclaim the gospel with unfailing courage.

According to 1:21 Paul's death is gain for two reasons. First, it means being with Christ, who is his life. Secondly, his martyrdom and execution will lead to the progress of the gospel. As such it recalls the ironic turn of events in 1:12.

In 1:22 the syntactic problem is the result of the tension between Paul's personal desire and his Christian duty. Such psychological pressure could only be shared with friends and provides proof of the strong relationship between himself and the Philippians.

Paul's dilemma is expressed clearly in 1:23-24. The abbreviated sentences used from 1:20 up to 1:24 enhance the forcefulness of his statements, while $\delta \iota^{\prime}$ i $\mu a \hat{s}$ at the end of 1:24 implies that there were serious problems in Philippi - a situation to which the letter as such is responding.

In 1:25-26 Paul reassures the Philippians by describing the three purposes of his release: their progress in the faith, their joy in the faith and their exultation through his ministry among them. кaì тоитто $\pi \epsilon \pi \circ \theta \dot{\omega} s$ oi $\delta a$ at the beginning of 1:25 could be described as an expression of firm conviction, assuring the Philippians in a powerful way that he will remain with them. The combination $\mu \in \nu \hat{\omega}$ кaì $\pi a \rho a \mu \in \nu \widehat{\omega}$, as a form of stylistic reinforcement, serves the same purpose. The

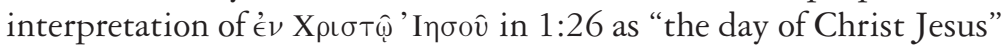
is supported by the context and, with the prospect of Paul's return, assure joy for the Philippians.

The following supportive rhetorical techniques have been identified:

- the hendiadys in 1:20 that serves to connect the concepts ámoкa-

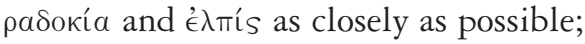

- $\quad$ Éroí at the beginning of 1:21, emphasising Paul's own experience in contrast to those who proclaim the gospel with impure motives, and

- the assonance in $1: 21$, stressing the content of what is said in a singularly focused way. 


\section{CONCLUSION}

A typical rhetorical analysis with its focus on external rhetorical categories being forced upon a text, only takes us a limited way in understanding Paul's rhetorical strategy. In this article the letter itself was the starting-point for the analysis and Paul's rhetorical strategy was constructed from the text.

The basic rhetorical strategy in 1:12-26 could be described as: "Reassuring the Philippians by informing them that his imprisonment and possible execution are for the advancement of the gospel." Philippians 1:12-26 was divided in two phases, demarcated by rhetorical considerations: 1:12-17 (informing the Philippians that his imprisonment was for the advancement of the gospel); and 1:18-26 (informing them that his adversities will result in his salvation and the progress of the gospel). Both phases are aimed at assuring the Philippians that his personal circumstances have resulted in the progress of the gospel and are thus reason for intense joy.

This assurance is in response to a situation where the Philippians were experiencing serious problems, lost their sense of Christian joy and were uncertain about the implications of Paul's imprisonment. The assurance is given by using various rhetorical strategies and techniques. In analysing these, the focus was on exegetical issues that could have a rhetorical impact, on the types of arguments used, on the way Paul argues and on rhetorical techniques that could enhance the impact of the communication. At least four examples of an argument based on divine involvement have been identified, while emotional techniques, techniques to capture the attention of the audience, repetition of terms for stylistic reinforcement, the use of brief sentences, striking metaphors, chiasms, etc. all contribute to the impact of Paul's argumentation and serve to assure the Philippians of the progress of the gospel as a result of his circumstances. 


\section{BIBLIOGRAPHY}

\section{ANDERSON R D}

1999. Ancient rhetorical theory and Paul. Leuven: Peeters. CBET 18.

\section{ARNDT W F \& GINGRICH F W}

1957. A Greek-English lexicon of the New Testament and other early Christian literature. Chicago: University Press.

\section{BETZ H D}

1979. Galatians. A commentary of Paul's Letter to the churches in Galatia. Philadelphia: Fortress.

\section{BROWN R E}

1997. An introduction to the New Testament: Letter to the Philippians. New York, London, Toronto, Sydney, Auckland; Doubleday. The Anchor Bible Reference Library.

\section{BRUCE F F}

1984. Philippians. Aylesbury: Pickering and Inglis. Good News Bible Commentary.

\section{Classen C J}

1993. St. Paul's Epistles and Ancient Greek and Roman Rhetoric. In: S.E. Porter \& T.H. Olbricht (eds.), Rhetoric and the New Testament. Essays from the 1992 Heidelberg Conference (Sheffield: JSOT Press), pp. 264-291.

\section{Collange J F}

1979. The Epistle of Saint Paul to the Philippians. Translated by A.W. Heathcote. London: Epworth Press.

\section{FEE G D}

1995. Paul's Letter to the Philippians. Michigan, Grand Rapids: W.B. Eerdmans Publishing Company. The New International Commentary on the New Testament.

GNILKA J

1976. Der Philipperbrief. Basel: Herder.

\section{HENDRIKSEN W}

1962. Philppians. Grand Rapids: Baker. New Testament Commentary.

\section{KERN P H}

1998. Rhetoric and Galatians. Assessing an approach to Paul's Epistle. Cambridge: Cambridge University Press. SNTS. MS101.

LOH I J \& NiDA E A

1977. A translators handbook on Paul's Letter to the Philippians. Stuttgart: United Bible Societies. Helps for Translators 19.

\section{LOUW J P \& NidA E A}

1988. Greek-English lexicon of the New Testament based on semantic domains. New York: United Bible Societies. 
MARShall P

1987. Enmity in Corinth. Tübingen: WUNT 2/23.

\section{MATTER HM}

1965. De Brief van Paulus aan de Philippenzen en de Brief aan Philemon. Commentaar op het Nieuwe Testament. Kampen: JH Kok.

\section{MÜLLER J J}

1976. The Epistles of Paul to the Philippians and Philemon. Michigan, Grand Rapids: W.B. Eerdmans Publishing Company. The New International Commentary on the New Testament.

\section{MÜller U B}

1993. Der Brief des Paulus an die Philipper. Leipzig: Evangelische Verlagsanstalt. Theologischer Handkommentar zum Neuen Testament.

\section{O'BRIEN P T}

1991. The Epistle to the Philippians. Michigan, Grand Rapids: W.B. Eerdmans Publishing Company.

\section{OSBURN C D}

1971. A Bible translator's handbook on Philippians. Michigan, Ann Arbor: University Microfilms Inc.

\section{SCHENK W}

1984. Die Philipperbrief des Paulus. Kommentar. Stuttgart: W. Kohlhammer.

\section{SILVA M}

1988. Pbilippians. Chicago: Moody Press. The Wycliffe Exegetical Commentary.

\section{TOlMIE D F}

2000. Paulus se retoriese strategie in Galasiërs 1:1-10. Acta Theologica 20(2): 122-137.

2000. Enkele vertaalprobleme in die vertaling van die Filippensebrief in die 1983 Afrikaanse vertaling. NGTT 41(2):217-227.

2004. A rhetorical analysis of the letter to the Galatians. Ph. D. dissertation. Bloemfontein: University of the Free State.

\section{WATSON D F}

1988. A rhetorical analysis of Philippians and its implications for the unity question. Novum Testamentum 30:57-88.

Keywords

Pauline Letters

Philippians 1:12-26

Rhetorical analysis
Trefwoorde

Pauliniese Briewe

Filippense 1:12-26

Retoriese analise 